\title{
COSC-2 - drilling the basal décollement and underlying margin of palaeocontinent Baltica in the Paleozoic Caledonide Orogen of Scandinavia
}

\author{
Henning Lorenz ${ }^{1}$, Jan-Erik Rosberg ${ }^{2}$, Christopher Juhlin ${ }^{1}$, Iwona Klonowska ${ }^{3}$, Rodolphe Lescoutre ${ }^{1}$, \\ George Westmeijer ${ }^{4}$, Bjarne S. G. Almqvist ${ }^{1}$, Mark Anderson ${ }^{5}$, Stefan Bertilsson ${ }^{6}$, Mark Dopson ${ }^{4}$, \\ Jens Kallmeyer ${ }^{7}$, Jochem Kück ${ }^{8}$, Oliver Lehnert ${ }^{9}$, Luca Menegon ${ }^{10}$, Christophe Pascal ${ }^{11}$, \\ Simon Rejkjær ${ }^{2}$, and Nick N. W. Roberts ${ }^{12}$ \\ ${ }^{1}$ Department of Earth Sciences, Uppsala University, Villavägen 16, 75236 Uppsala, Sweden \\ ${ }^{2}$ Engineering Geology, Lund University, John Ericssons väg 1, 22100 Lund, Sweden \\ ${ }^{3}$ Faculty of Geology, Geophysics and Environment Protection, AGH University of Science and Technology, \\ al. Mickiewicza 30, 30-059 Kraków, Poland \\ ${ }^{4}$ Centre for Ecology and Evolution in Microbial Model Systems (EEMiS) Linnæus University, \\ Stuvaregatan 4, 39231 Kalmar, Sweden \\ ${ }^{5}$ School of Geography, Earth and Environmental Sciences, University of Plymouth, \\ B527 Portland Square, Plymouth PL4 8AA, United Kingdom \\ ${ }^{6}$ Department of Aquatic Sciences and Assessment, Swedish University of Agricultural Sciences, \\ Lennart Hjelms väg 9, 75651 Uppsala, Sweden \\ ${ }^{7}$ Section 3.7 Geomicrobiology, GFZ German Research Centre for Geosciences, \\ Telegrafenberg, 14473 Potsdam, Germany \\ ${ }^{8}$ Section 4.2: Geomechanics and Scientific Drilling, GFZ German Research Centre for Geosciences, \\ Telegrafenberg, 14473 Potsdam, Germany \\ ${ }^{9}$ Geozentrum Nordbayern, Friedrich-Alexander University Erlangen-Nuremberg, \\ Schloßgarten 5, 91054 Erlangen, Germany \\ ${ }^{10}$ Njord Centre, Department of Geosciences, University of Oslo, Sem Sælands vei 24, 0371 Oslo, Norway \\ ${ }^{11}$ Institute of Geology, Mineralogy and Geophysics, Ruhr University Bochum, \\ Universitätsstraße 150, 44780 Bochum, Germany \\ ${ }^{12}$ NERC Isotope Geosciences Laboratory, British Geological Survey, Nottingham NG12 5GG, United Kingdom \\ Correspondence: Henning Lorenz (henning.lorenz@geo.uu.se)
}

Received: 31 August 2021 - Revised: 17 January 2022 - Accepted: 23 January 2022 - Published: 25 February 2022

\begin{abstract}
The Collisional Orogeny in the Scandinavian Caledonides (COSC) scientific drilling project aims to characterise the structure and orogenic processes involved in a major collisional mountain belt by multidisciplinary geoscientific research. Located in western central Sweden, the project has drilled two fully cored deep boreholes into the bedrock of the deeply eroded Early Paleozoic Caledonide Orogen. COSC-1 (2014) drilled a subduction-related allochthon and the associated thrust zone. COSC-2 (2020, this paper) extends this section deeper through the underlying nappes (Lower Allochthon), the main Caledonian décollement, and the upper kilometre of basement rocks. COSC-2 targets include the characterisation of orogen-scale detachments, the impact of orogenesis on the basement below the detachment, and the Early Paleozoic palaeoenvironment on the outer margin of palaeocontinent Baltica. This is complemented by research on heat flow, groundwater flow, and the characterisation of the microbial community in the present hard rock environment of the relict mountain belt. COSC-2 successfully, and within budget, recovered a continuous drill core to $2276 \mathrm{~m}$ depth. The retrieved geological section is partially different from the expected geological section with respect to the depth to the main décollement and the expected rock types. Although the intensity of synsedimentary deformation in the rocks in
\end{abstract}


the upper part of the drill core might impede the analysis of the Early Paleozoic palaeoenvironment, the superb quality of the drill core and the borehole will facilitate research on the remaining targets and beyond. Protocols for sampling in the hard rock environment and subsequent sample preservation were established for geomicrobiological research and rock mechanical testing. For the former, a sparse sample series along the entire drill core was taken, while the target of the latter was the décollement. COSC-2 was surveyed by a comprehensive postdrilling downhole logging campaign and a combined borehole/land seismic survey in autumn 2021. This paper provides an overview of the COSC-2 (International Continental Scientific Drilling Project - ICDP 5054_2_A and 5054_2_B boreholes) operations and preliminary results. It will be complemented by a detailed operational report and data publication.

\section{Insights into the lowermost level of a major collisional orogen}

The Caledonides are a mid-Paleozoic collisional orogen of Alpine-Himalayan dimension. During closure of the Iapetus Ocean, the palaeocontinent Baltica underthrusted the palaeocontinent Laurentia in the Silurian and Early Devonian. Today, after the opening of the Atlantic Ocean in the Paleogene, remains of the deeply eroded mountain belt are preserved in the continental margins of Greenland and Scandinavia and expose the interior of this major collisional orogen for geoscientific investigations. In Scandinavia, the continental margin is composed of Baltican basement overlain by a stack of increasingly distal allochthons that were emplaced during Caledonian (Scandian) orogeny, having been transported up to several hundreds of kilometres (e.g. Gee et al., 2008). The primary target of the Collisional Orogeny in the Scandinavian Caledonides (COSC) scientific drilling project (Fig. 1) is to study orogenic processes at various scales along a continuous section through the interior of this deeply eroded mountain belt, from the high-grade metamorphic, subduction-related allochthons derived from the distal margin of Baltica, known as the Middle Allochthon, through the low-grade metamorphic continental margin sediments of the Lower Allochthon, the main Caledonian décollement and into the underlying sedimentary basement cover, and, at the deepest level, the crystalline basement of palaeocontinent Baltica (i.e. the Baltoscandian basement of the Fennoscandian Shield). The COSC project comprises two sites, namely COSC-1 drilled in 2014 and COSC-2 drilled in 2020. COSC-1 is located close to the timberline on the eastern slopes of the Åreskutan mountain, with subductionrelated ultra high pressure metamorphic rocks of the Middle Seve Nappe exposed on its summit and upper slopes (Klonowska et al., 2017). This drill core samples the underlying gneisses of the Lower Seve Nappe and thrust zone (see Lorenz et al., 2015a for science report and more extensive project background). COSC-2 (this paper) is located ca. $20 \mathrm{~km}$ southeast of COSC-1 at the southern shore of the Liten Lake. It starts at a tectonostratigraphic level, below that of the bottom of COSC-1, and samples the low-grade metamorphic siliciclastics of the Lower Allochthon, the main Cale- donian décollement, and the Baltoscandian basement, as detailed further below. Thus, the COSC project now has access to a composite geological section spanning the lower part of the Caledonide orogen, from the hot allochthon of the Seve Nappe and into the basement of the lower plate. Ongoing research is testing different hypotheses of nappe emplacement through an investigation of the kinematics and thermochronological development of the different allochthons and their interaction with the basement of the underthrusting plate in this major collisional orogen.

\section{2 cosc-2 objectives}

The COSC-2 objectives are derived from the COSC project targets (e.g. Gee et al., 2010) by careful evaluation of the geological premises (site investigations) and practical and financial feasibility. They are formulated here as the scientific targets and geological section that was expected to be drilled with the available resources. The selection of the drill site was based on the geological interpretation of the reflection seismic and magnetotelluric site investigations (Juhlin et al., 2016), of which detail on the drill site is shown in Fig. 2.

\subsection{Scientific targets}

1. The lower part of the COSC composite geological section, i.e. the COSC- 2 drill core, will provide an opportunity for increased understanding of the main Caledonian décollement and associated fault systems, including geometry, stress distribution, and rheology. These investigations will also shed light on how deformation propagated below this orogen-scale detachment horizon into the basement of the Fennoscandian Shield and whether a deeper deformation system played a role in the tectonic cycle from Iapetus formation to the present-day Atlantic.

2. The origin and nature of the prominent, deep basement reflectors imaged in the seismic profiles and their role during passive margin formation and orogeny is a key question in the context of point (1). Eventually, these new insights will utilise analogue studies with modern orogens like the Alpine-Himalayan mountain belt. 


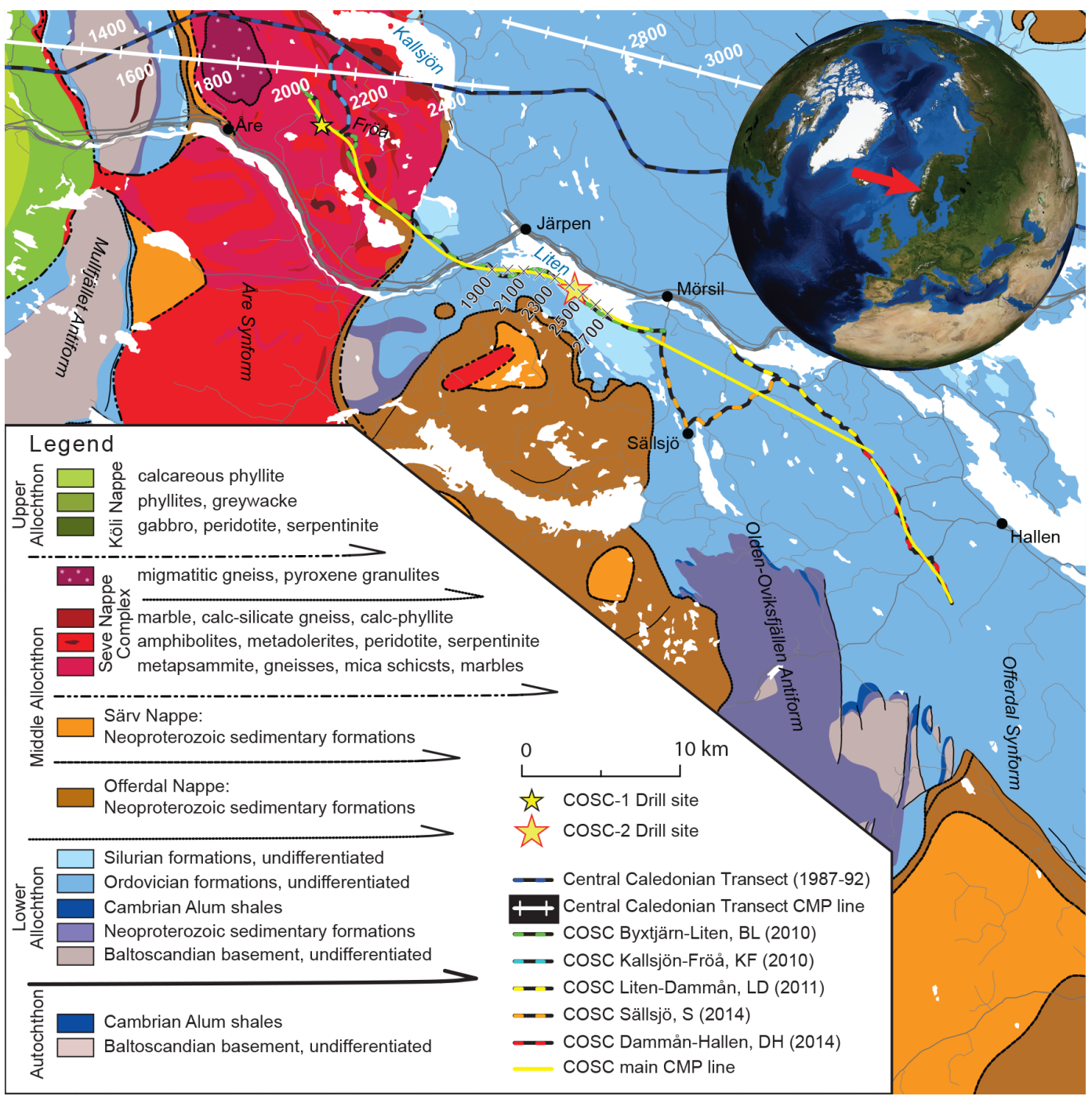

Figure 1. Tectonostratigraphic map of the Åre-Järpen area (based on the 1:200000 scale geological map by the Geological Survey of Sweden, I2014/00601; Strömberg et al., 1984). The map shows the COSC drill sites, the location of the regional seismic profiles of the Central Caledonian Transect (Palm and Lund, 1980; Juhojuntti et al., 2001), and the seismic lines of the COSC site investigations. Note that the common depth point (CDP) on the latter were shifted during reprocessing and, thus, are different from Hedin et al. (2012) and Juhlin et al. (2016). The magnetotelluric survey (Yan et al., 2016) followed the track of the COSC seismics. Figure modified from Juhlin et al. (2016).

3. The Early Paleozoic sediments drilled by COSC-2 were deposited on the continental margin before Scandian orogeny and, subsequently, during orogeny, into a foreland basin. As the most distal location in a multiplesite study of this Paleozoic basin, COSC-2 will add unique information on palaeoenvironmental conditions and facilitate the reconstruction of the palaeoclimate, global biologic crises, faunal turnover, and major glacial events.

4. More recent climate evolution is addressed with the study of the ground surface temperature history, based on high-quality, high-resolution borehole temperature profiles. The two COSC drill sites are situated just east of the ice divide of the Weichselian ice sheet in Fennoscandia but in locations with different (palaeo)environmental and altitude conditions, with COSC- 1 on the lower slope of a mountain and COSC2 in a glacial valley. Thus, COSC will contribute to knowledge about the Weichselian glaciation and climate evolution in northern Europe during the Holocene, including industrial age trends.

5. The hydrogeological and thermal characteristics of mountain belts are defined by their geological history and structure, including for those that are already deeply eroded. Paleozoic orogens exist on all continents and are part of the lithosphere from Central Asia to Europe and 


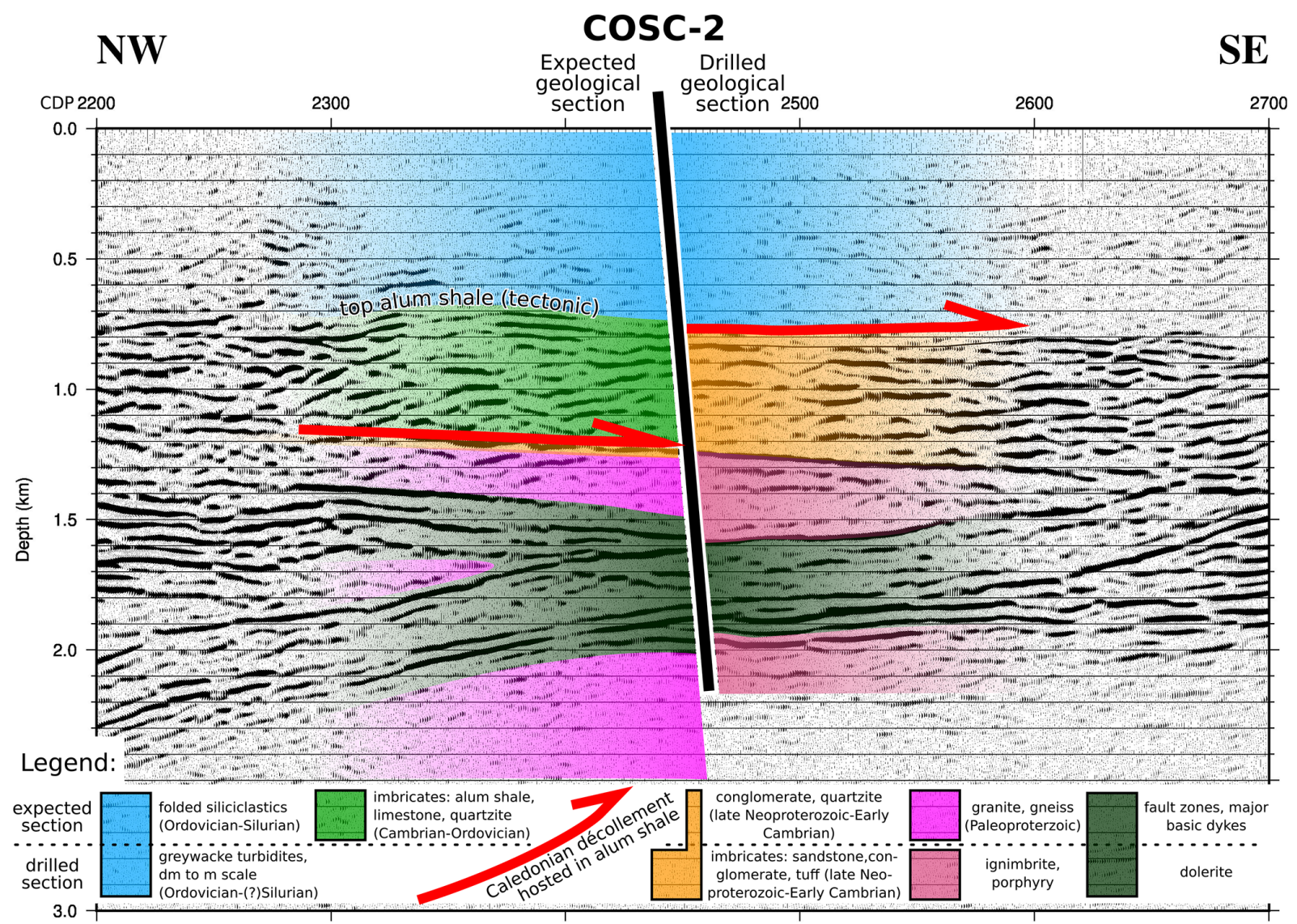

Figure 2. The COSC-2 expected geology (left) and the drilled geology (right) superimposed on the depth-converted seismic section that represents the rock in the vicinity of the COSC-2 drill site. See Fig. 1 for the location and note that, due to reprocessing, CDP points are shifted when compared with the original publications (Hedin et al., 2012; Juhlin et al., 2016).

western North America. COSC-2 investigates how the deep structure of the Scandinavian Caledonides, including large-scale detachments and basement deformation, affect hydraulic conductivity, pressure heads, and heat transfer in the interplay with groundwater flow and concomitant advective heat transport. Eventually, this will increase the understanding about the origin and genesis of fluids and gases and their impact on seismicity and rheology over time.

6. Microbiological research focuses on changes in microbiological community composition as a function of depth and lithology and to investigate long-term evolutionary change. A secondary target is to benchmark and validate the dedicated triple-tube coring and onsite drill core sampling for contamination-free microbial sampling. Strict contamination control ensures the integrity of the sample collection and provides a test bed for protocols to be used for future scientific boreholes dedicated to microbial research. In addition, fracture mineralisation will undergo detailed geochemical and isotopic characterisation, as this can reveal infor- mation on the timing and nature of microbial activity through deep time.

\subsection{Expected geological section}

The expected geological section is based on the interpretation of the geophysical site investigations, which are detailed in Juhlin et al. (2016). At ca. 1200-1250 m depth, a laterally extensive and nearly continuous reflection is present in the seismic section (Fig. 2). It was interpreted as being the detachment between the Lower Allochthon and the autochthonous basement, i.e. the main Caledonian décollement. This inferred detachment was interpreted as being hosted and facilitated by the highly organic-rich and electrically conductive Early to Middle Cambrian Alum Shale Formation (Andersson et al., 1985), and thus, this depth was also interpreted as being the depth to the formation's stratigraphic occurrence. However, the magnetotelluric survey (Yan et al., 2016) predicted the first occurrence of a good conductor, i.e. Alum Shale, already at ca. $750 \mathrm{~m}$ depth. Based on this interpretation and the occurrence of Late Ordovician to Early Silurian formations (Kogsta Shale, Ede Quartzite, and Berge 
Limestone) in the hills south of the drill site, the borehole was expected to start in or below these formations and extend downwards through turbiditic greywackes, shales, and siltstones (Föllinge and Andersön formations; light blue in Fig. 2) and penetrate the shallowest occurrence of Alum Shale at ca. $750 \mathrm{~m}$. Based on the seismic pattern, the rocks below this depth and down to the décollement (light green in Fig. 2) were interpreted as being an imbricate system consisting of Alum Shale, varying Ordovician limestones, and possibly overlying greywackes (see Karis and Strömberg, 1998, for a detailed description of the stratigraphy). After sampling the Paleozoic section (scientific target 3), including the décollement in the Alum Shale Formation (scientific target 1), the drilling target shifts to the basement. This section was expected to start with a thin layer of Neoproterozoic Vemdalen Quartzite (orange in Fig. 2), which in many (but not all) areas covers the Paleoproterozoic basement (pink in Fig. 2) of ca. 1.7 Ga Rätan granite (see Gorbatschev, 1997; Högdahl et al., 2004). The latter is a major intrusive body that makes up an area of about $5000 \mathrm{~km}^{2}$ east of the present Caledonian front. Based on magnetic data, it is inferred to extend northwestwards, far below the Caledonian nappes and including the COSC area (Dyrelius, 1980). In addition, the Dala Porphyries (also ca. 1.7 Ga; Welin et al., 1993) extend beneath the Caledonian nappes from their type area $200 \mathrm{~km}$ to the south, and similar rocks (basement porphyries) have been reported in basement windows (Mullfjället; Beckholmen, 1978) and tectonic slices (Östberget on Frösön; Karis and Strömberg, 1998). Thus, to encounter such rocks in the borehole was regarded as being possible, although not very likely. In the basement, bedrock would be sampled that corresponds to a prominent series of reflections between about 1.5 and $2.0 \mathrm{~km}$ (scientific target 2; olive green in Fig. 2) and which were interpreted to either be (1) major fault zones of yet unknown, but possibly Caledonian age, (2) dolerite intrusions related to the Central Scandinavian Dolerite Group (ca. $1.25 \mathrm{Ga}$; Gorbatschev et al., 1979), or (3) a combination of both. Drilling would stop, and the borehole would be completed once the nature of the basement rocks beneath these reflections was established.

\section{Technical operations}

The drilling operations aimed at full-core coverage from the surface to total depth. For this purpose, two boreholes were drilled, namely COSC-2A and COSC-2B (Table 1). Total core recovery was slightly higher than the total cored length. This indicates that the actual core recovery is very close to $100 \%$, while the positive error most likely is due to the minimal but repeatedly added distance across fractures in the pieced-together drill core.

The COSC-2 drill site (Fig. 3) has a size of $1600 \mathrm{~m}^{2}$ and is constructed from compacted soil covered by a geotextile and graded crushed stone. A $1.2 \mathrm{~m}$ deep circular cellar was

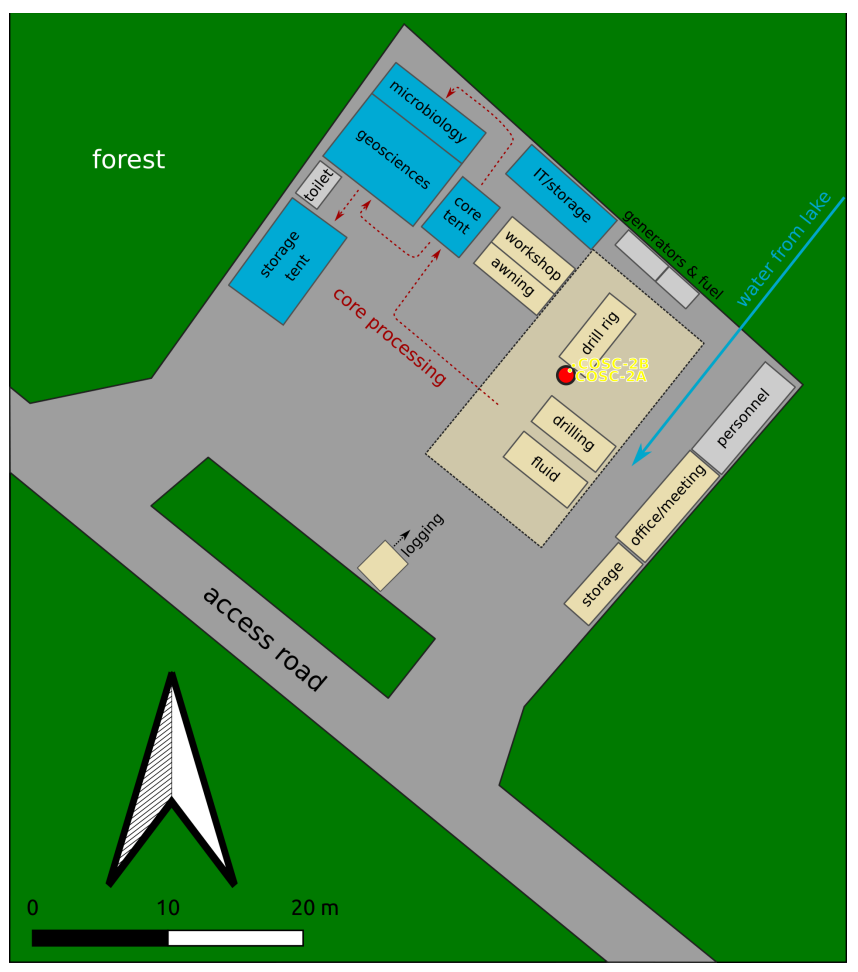

Figure 3. Sketch of the COSC-2 drill site. The area is approximately $1600 \mathrm{~m}^{2}$ large, with the northwestern half used for the science operations (blue), parking, and storage and the southeastern half used for the technical operations (yellow) and common facilities. The route of the core from drilling deck to storage is marked in red.

built using concrete rings with an inner diameter of $1.2 \mathrm{~m}$, with the bottom sealed with cement. Electricity at the drill site was supplied by generators, and Liten Lake was used as the water supply. Preparations for the deep-core drilling of borehole COSC-2A started with the installation of a $9 \mathrm{~m}$ long surface casing, with an outer diameter (OD) of $193.7 \mathrm{~mm}$ and an inner diameter (ID) of $183.7 \mathrm{~mm}$. Thereafter a $165 \mathrm{~mm}$ borehole was drilled down to $100 \mathrm{~m}$, using air percussion drilling, and a surface casing (OD $139.7 \mathrm{~mm}$; ID $129.7 \mathrm{~mm}$ ) was installed and cemented from bottom to surface. Before drilling, a second casing string (HWT casing; OD $114.3 \mathrm{~mm}$; ID $101.6 \mathrm{~mm}$ ) was cemented from the casing shoe at $100 \mathrm{~m}$ to the surface. The smaller diameter reduces the risk for damage to the drill string and guarantees proper transport of cuttings. In addition, a second short casing was installed to $6 \mathrm{~m}$ depth, just outside the well cellar. It was first used as support for the drill rig and later as the conductor casing for borehole COSC-2B, with the purpose to core the upper $100 \mathrm{~m}$ that were hammer-drilled in COSC-2A.

The COSC-2A drilling operation started on 14 April 2020 and was completed on 7 August 2020 at a total depth of $2276 \mathrm{~m}$. It was only interrupted for $18 \mathrm{~h}$ per week while drilling crews changed. For drilling, the Swedish national re- 
Table 1. The COSC-2 boreholes. Locations are from real-time kinematic positioning (RTK) global navigation satellite system (GNSS), the geodetic datum is WGS84 (EPSG:4326), and elevation is RH2000 (EPSG:5613). The recovered core is slightly longer than the totally cored length. Note: IGSN - International Geo Sample Number.

\begin{tabular}{|c|c|c|c|c|c|c|c|c|}
\hline Name & Designation & IGSN & $\begin{array}{r}\text { Driller's } \\
\text { depth } \\
(\mathrm{m})\end{array}$ & $\begin{array}{l}\text { Cored } \\
\text { length } \\
(\mathrm{m})\end{array}$ & $\begin{array}{r}\text { Core } \\
\text { recovered } \\
(\mathrm{m})\end{array}$ & Latitude & Longitude & $\begin{array}{l}\text { Elevation } \\
(\mathrm{m})\end{array}$ \\
\hline COSC-2B & 5054-2-B & ICDP5054EH50001 & 116.25 & 110.2 & 110.5 & $63.31244644^{\circ} \mathrm{N}$ & $013.52648032^{\circ} \mathrm{E}$ & $320.31^{\mathrm{b}}$ \\
\hline
\end{tabular}

a Elevation reference for borehole in the cellar is ground elevation. ${ }^{\mathrm{b}}$ Elevation reference for borehole outside the cellar is the top of the casing.

search infrastructure for scientific drilling at Lund University, Riksriggen, was staffed with three drillers and/or assistants per $12 \mathrm{~h}$ shift. The drilling fluid was recirculated during the drilling, and the cuttings were removed by gravitational settling in two compartmentalised $10 \mathrm{~m}^{3}$ tanks. The tank contents were disposed of in compliance with environmental regulations. A specially designed well head, including a main valve, an annular blow-out preventer (BOP), and a kill line, was used as a safety precaution during the drilling (see Lorenz et al., 2015a, b). In addition, a gas detector was placed on the drill floor, primarily for the potential hazard of $\mathrm{H}_{2} \mathrm{~S}$ from the Alum Shale Formation. The drilling was conducted as continuous wire line core drilling, and all core assemblies were extended with the core orientation tool REFLEX ACT III ${ }^{\mathrm{TM}} \mathrm{RD}$ (rapid descent).

HQ3 (triple tube) core drilling (3 m core barrel length; hole diameter $96.0 \mathrm{~mm}$; core diameter $61.1 \mathrm{~mm}$ ) used water without additives as a drilling fluid and stopped at $1576 \mathrm{~m}$ depth, where the drill string was installed as a temporary casing. The drilling continued with NQ3 (3 m core barrel length; hole diameter $75.7 \mathrm{~mm}$; core diameter $45.0 \mathrm{~mm}$ ) from 1576 to $1883 \mathrm{~m}$ depth. From $1850 \mathrm{~m}$ downwards, a biodegradable polymer (AMC FS $2000^{\mathrm{TM}}$ ) was added to the drilling fluid to reduce friction and facilitate the transport of cuttings. After evaluating the high core recovery and the rock quality, it was decided to change to NQ double-tube drilling ( $6 \mathrm{~m}$ core barrel length; $75.7 \mathrm{~mm}$ hole diameter; $47.8 \mathrm{~mm}$ core diameter) to save time, leading to an approximately $30 \%-40 \%$ time saving due to the longer core barrel and, thus, reduced winching time at this depth. NQ drilling started at $1883 \mathrm{~m}$ and continued to total depth (TD) at $2276 \mathrm{~m}$.

COSC-2A was flushed clean and left with the casing to $100 \mathrm{~m}$ depth and an open-hole completion below. The procedure was similar to COSC-1A (see Lorenz et al., 2015a, b) and left the borehole in a state that is suitable for the downhole surveys that address the scientific targets (4) and (5). In summary, the drilling proceeded well, with high core recovery, and the operation was completed within budget. However, and similar to COSC-1, the drilling was affected by deforming drill rods, which increased friction in the borehole and the lowered revolutions per minute (rpm), thus affecting the penetration rate and bit life negatively. After the completion of COSC-2A, the drill rig was moved slightly and COSC-2B was core drilled in HQ3 down to $116 \mathrm{~m}$ depth within $2 \mathrm{~d}$.

COSC-2A was logged by Riksriggen (Lund University) during drilling breaks for preliminary scientific assessment and to secure data in case of a hole loss. An extensive downhole survey in both boreholes was conducted from 8 to 14 September 2020 by ICDP (International Continental Scientific Drilling Project) OSG (Operational Support Group) and Riksriggen (Lund University).

\section{Scientific operations and material}

The scientific operations planned for COSC-2 resembled closely those of the successful COSC-1 drilling (as described in Lorenz et al., 2015a, b) but with some minor improvements and the addition of an on-site microbiologist during the entire drilling period (scientific target 6). However, as the COVID-19 pandemic struck, the options were either to delay the entire drilling or to continue with a curtailed on-site programme that could be handled entirely by personnel based in Sweden. The latter option was chosen, as the risk of a prolonged delay due to the then-unknown development of the pandemic was judged higher than the disadvantages caused by the absence of foreign personnel and scientific experts while drilling. Eventually, the following curtailments were implemented: the detailed geological drill core description was postponed to the core repository due to insufficient availability of geologists, and online gas monitoring (Wiersberg et al., 2020) had to be cancelled since the necessary equipment was caught in the lockdown. Depending on the depth and drilling progress, one to two scientists per $12 \mathrm{~h}$ shift worked on the curation and documentation of the drill core. The latter included the registration of metadata, initial geological assessment, core scans, multi-sensor core logging (MSCL), core box photography, and packaging for transport. On-site sampling was restricted to microbiology and a sample series that was taken from the interval across the main Caledonian décollement (scientific targets 1 and 6).

For the microbiology, core samples $20-30 \mathrm{~cm}$ in length were collected from a depth of 100 to $2250 \mathrm{~m}$ at $50 \mathrm{~m}$ intervals, resulting in a total of 50 core samples. After sam- 
ple registration in the mDIS (Drilling Information System), the surface of the core was washed with sterile Milli-Q ultrapure water and brought to the on-site microbiology laboratory. The bench tops used for core processing were chemically disinfected, followed by flame sterilisation. The surface of the core was flamed to combust contaminating nucleic acids from microbes present in the drilling fluid. To assess the success of surface decontamination, fluorescent microspheres (AFN-09, Radiant Color NV) $0.25-0.45 \mu \mathrm{m}$ in diameter were added to the drilling fluid at a final concentration range of $10^{8}$ to $10^{9}$ beads per millilitre. The concentration of the microspheres in the drilling fluid was determined every $6 \mathrm{~h}$ using a fluorescent microscope (CyScope HP equipped with a $470 \mathrm{~nm}$ LED set), as previously described (Friese et al., 2017). Simultaneous with the core recovery, $50 \mathrm{~mL}$ of the drilling fluid was sampled in a sterile Falcon tube and immediately frozen at $-80^{\circ} \mathrm{C}$ for the characterisation of the microbial community in the drilling fluid and, thus, to determine which taxa should be considered as contaminants. An evaluation of the core surface sterilisation was carried out, as previously described (Friese et al., 2017), or via an adapted surface sterilisation protocol described as follows. Briefly, a surface fragment of $2-3 \mathrm{~g}$ was collected, using a sterile chisel, and washed for $5 \mathrm{~min}$ in sterile Milli-Q water $(1 \mathrm{~mL}$ water per gram of rock) using a vortex. The liquid was filtered on a polycarbonate membrane filter, and the bead concentration on the core's surface was estimated by counting 30 random fields of view using fluorescent microscopy. Flame sterilisation of the core surface was repeated until at least $99.9 \%$ of the microspheres in the drilling liquid had been quenched (quenching of the microsphere fluorescence occurs upon heating above $100^{\circ} \mathrm{C}$ ). Once the core was deemed free from contamination, it was sampled for subsequent CARDFISH analysis (fluorescence in situ hybridisation with catalysed reporter deposition; Escudero et al., 2020). Briefly, the core was transferred to the clean part of the on-site laboratory to sample the inner core, by aseptically removing small fragments, followed by fixing the material in $4 \%$ ( $\mathrm{vol} / \mathrm{vol}$ ) formaldehyde in Mackintosh minimal media. The fixed sample was stored at $4{ }^{\circ} \mathrm{C}$ until transport back to the home laboratory, where it was kept at $-20^{\circ} \mathrm{C}$. Finally, the core was packaged in a foil sleeve, partially sealed, flushed with $0.2 \mu \mathrm{m}$ filtered nitrogen gas, completely sealed, and stored in a $-80^{\circ} \mathrm{C}$ freezer present on site. Due to the adhesion of the fluorescent microspheres to the clay particles in the drilling fluid, the beads were no longer added to the drilling fluid after reaching $700 \mathrm{~m}$ depth. As an alternative decontamination control procedure, the microbiology core was, immediately after retrieval, submersed in a liquid containing the fluorescent microspheres in a concentration of $10^{8}$ to $10^{9}$ beads per millilitre, followed by the same decontamination procedure as described above. In addition to the $50 \mathrm{~m}$ sample interval, natural fractures were sampled by first rinsing the surrounding material with autoclaved Milli-Q water, whereafter the material was collected with either a flame-sterilised chisel or a spatula. The material was subsequently washed in $5 \mathrm{~mL}$ autoclaved Milli-Q water using a vortex and stored at $-80^{\circ} \mathrm{C}$. The drilling fluid was sampled directly after sampling the fracture in an identical manner to that described above. For natural fracture samples, it was not possible to flame the surface, as this would combust all biomolecules in the sample. Consequently, there is a higher risk of contamination of this material compared to the surface-sterilised cores; the significance and influence of this contamination will be assessed during characterisation of the microbial communities. Finally, all samples stored on site at $-80^{\circ} \mathrm{C}$ were transferred to the home laboratory on dry ice and kept at $-80^{\circ} \mathrm{C}$ before processing.

A total of 17 samples for rock mechanical tests, each between 20 and $30 \mathrm{~cm}$ long, were taken from the Alum Shale Formation and across the main Caledonian décollement, which corresponds to approximately one sample per core run in the depth range from 780 to $820 \mathrm{~m}$. Each sample was placed in a plastic pipe with a diameter slightly larger than the core diameter, and orientation marks were copied from the core to the pipe's outside. The pipe, whose bottom is closed, was then filled with laminating epoxy until the sample was covered completely. The cured epoxy preserves both the sample's fluid content and its structural integrity during transport to the laboratory.

In summary, the scientific material of the COSC-2 drilling consists of the drill core (sample material) and the following data sets:

- technical data acquired at the drill rig

- drill core metadata, as documented in the mDIS, e.g. core run, depth, core sections, length of sections, core recovery, and the location of sections in core boxes

- a preliminary geological overview

- unrolled core scans

- core box images

- geophysical parameters of the drill core measured with a Geotek Ltd. multi-sensor core logger (MSCL), with natural gamma, density, and magnetic susceptibility

- downhole logging data from Riksriggen (Lund University) and the ICDP OSG.

As the first major scientific drilling project that used the new mDIS software for the acquisition of on-site data, COSC-2 could demonstrate that this software is ready for production workflows after 2 years of development. The functionality of the mDIS is mission critical, as it captures the descriptive data of the drill core, including hierarchy, depth, and identifiers (see Conze et al., 2017). 


\subsection{Drill core}

Turbiditic greywackes of the Föllinge Formation were drilled from the bedrock surface at ca. $5 \mathrm{~m}$ depth and down to ca. $780 \mathrm{~m}$ (light blue in Fig. 2; Fig. 4a). Here, the borehole encountered a strongly sheared black shale unit, which is in accordance with the magnetotelluric site investigations (Fig. 4b). After ca. $45 \mathrm{~m}$, the black shales give way to a unit characterised by sandstones and conglomerates in a turbiditic background sedimentation, which extends downwards to ca. $1250 \mathrm{~m}$ (orange in Fig. 2; Fig. 4c). At this depth, ignimbrites and volcanic porphyries were encountered for the first time in the borehole (Fig. 4d). They show only minor signs of deformation and are present in different varieties (green to reddish; different grain sizes) down to the total depth (red in Fig. 2; Fig. 4e and g), interrupted by major (and some minor) dolerite intrusions between ca. 1600 and ca. $1930 \mathrm{~m}$ (green in Fig. 2; Fig. 4f), which show signs of deformation (cataclasite and breccia).

After the downhole logging operations, the drill core was depth corrected, as described in the next section. Thus, sample material, drill core data, and downhole data share a common depth system.

\subsection{Downhole logging and establishment of a common borehole reference system}

In COSC-2A, the following downhole measurements cover the entire, or at least the open (uncased), part of the borehole: caliper, temperature, magnetic susceptibility, formation resistivity, spectral gamma ray, full waveform sonic, and acoustic televiewer with borehole orientation. The sidewall density probe was deployed in the larger diameter (HQ) upper part of the borehole (to ca. $1570 \mathrm{~m}$ depth). The borehole was also surveyed with a north-seeking gyro probe (REFLEX GYRO SPRINT-IQ ${ }^{\mathrm{TM}}$ ) in multi-shot mode ( 25 and $50 \mathrm{~m}$ between measurement points). Caliper, formation resistivity and acoustic televiewer were measured in COSC-2B.

All probes include a natural gamma sensor for correlation between logs. First, a depth master log was established as master depth reference for COSC-2A and all other logs from the borehole depth-correlated to it. Then, the entire drill core was corrected to match the master depth reference. This was done by importing core scan images and televiewer imagery into Corelyzer software (https://github.com/corewall/ corelyzer, last acccess: 28 Jaunary 2022), where the depth of the unrolled core scans was adjusted until these images matched the structures observed in the acoustic televiewer imagery. The new core section depths were extracted to the mDIS system, which in turn integrates the new depth system into the drill core metadata and, thus, applies it to all core data (e.g. MSCL).

The depth reference for a borehole does not include information about the depth below surface. It is a local linear reference system along the borehole path. Thus, the bore- hole path is required for the calculation of the absolute depth below surface and a depth's relative location to the borehole origin. It is also necessary for the establishment of the absolute core orientation based on the core marking from the core orientation tool. COSC-2A was surveyed both with a north-seeking gyro probe (REFLEX GYRO SPRINT$\mathrm{IQ}^{\mathrm{TM}}$; rented) and the accelerometer-/magnetometer-based orientation of the acoustic televiewer probes, a Robertson Geologging High-Resolution Acoustic Televiewer (HiRAT; Riksriggen) and an ALT Abi43 (ICDP OSG). The gyro and televiewer orientation match closely (Fig. 5) but with a slightly higher deviation of the Abi43. Thus, the acoustic televiewer imagery can be regarded as an appropriate means for extracting drill core orientation (via the core scans and in addition to the depth correction), either for a confirmation of the results from the core orientation tool or as an independent assessment of a core section's orientation. Such a wellestablished borehole reference system will allow for the easy integration of all borehole data with established spatial reference systems (e.g. regional or national) and, thus, facilitates data comparison, interpretation, and integration (see Grellet et al., 2020).

\section{Preliminary scientific assessment}

COSC-2 reached all operational targets, with respect to drilling and downhole investigations, that were planned and required to properly address the scientific targets. The main curtailment of the operations due to the COVID-19 pandemic, i.e. the delay of the detailed geological drill core description from on-site work to core repository, was conducted and finalised recently (autumn 2021) at the core repository.

Comparing the expected geological section with the drilled section (Fig. 2) allows a number of observations. Although the drilling encountered strongly sheared Alum Shale at the predicted depth (Fig. 4b), this shale was not transported upwards from the décollement at about $1250 \mathrm{~m}$ in an imbricate system, as interpreted from site investigations. This ca. $45 \mathrm{~m}$ thick unit at $\sim 800 \mathrm{~m}$ is the Alum Shale Formation in its original stratigraphic position. The section below, down to ca. $1250 \mathrm{~m}$, is not the imbrication of the Lower Paleozoic related to deformation along the main Caledonian décollement in the Alum Shale but an imbrication with a possibly substantial thickening of the sedimentary basement cover. The latter is usually only up to some tens of metres thick and of Neoproterozoic age along the present exposed Caledonian front (Andersson et al., 1985; Juhlin et al., 2016). However, at COSC-2, the sedimentation of coarse siliciclastic sediments (sandstones and conglomerates) happened against a potentially younger turbiditic background sedimentation. The upper, drilled part of the basement consists of different Dala Porphyry varieties. The contact between basement and its clastic cover appears to be primary and not affected by deformation (Fig. 4d). Rocks of Rätan-type granite were not 

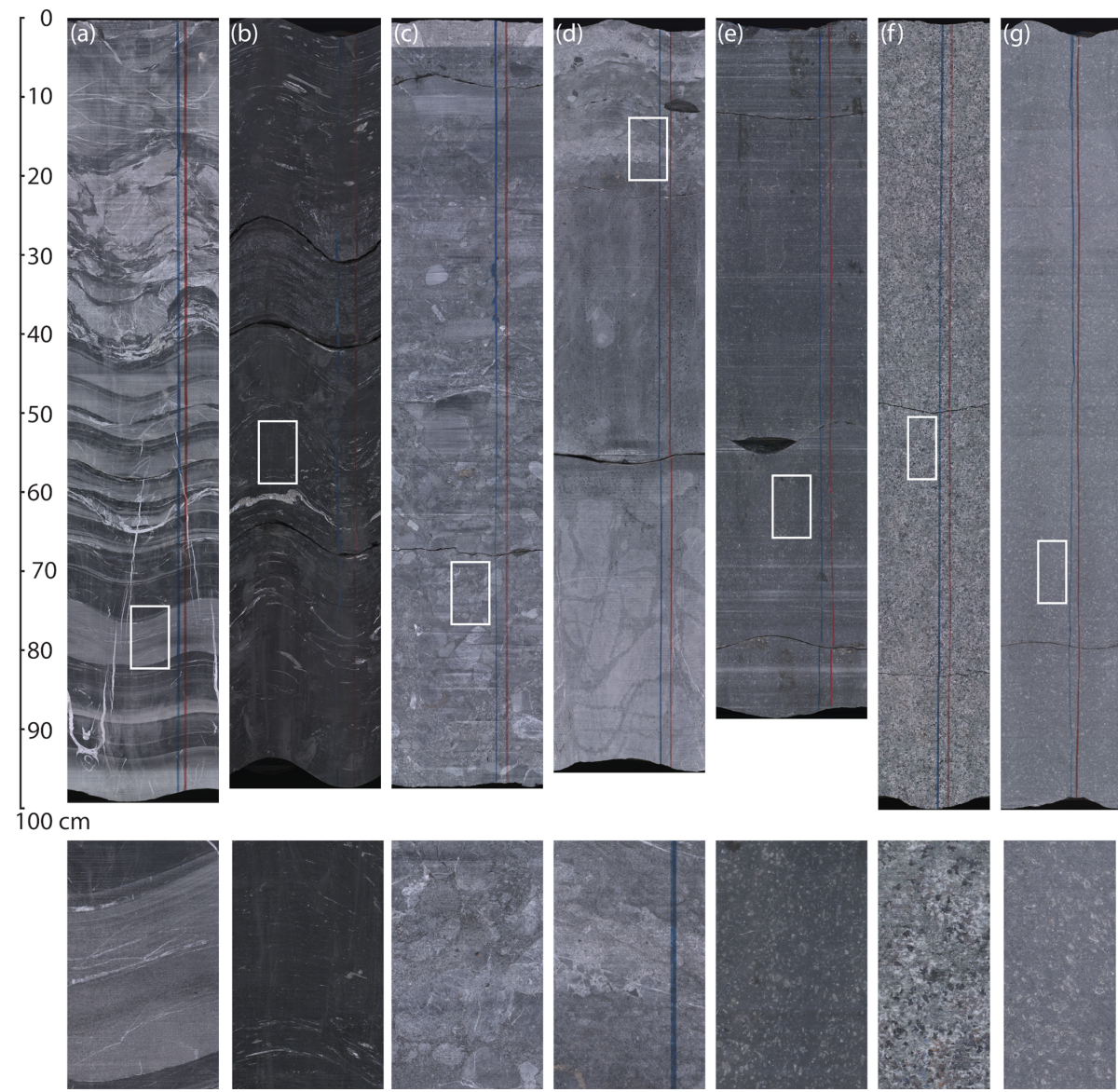

Figure 4. Examples for typical lithologies of the COSC-2 drill core. The upper row shows unrolled core scans of dry core sections (i.e. the entire core surface was scanned and is displayed as a flat image). Visible marks perpendicular to the core are usually caused by the drilling process. The lower row shows enlargements from the unrolled core scans (magnified 4 times when compared to upper row). For the location, see the white box in the corresponding image of the upper row. (a) Turbidites with slumping structures (section 91-3; 352 m depth). (b) Sheared Alum Shale (section 254-3; $817 \mathrm{~m}$ depth). (c) Conglomerate (in the clastic section between Alum Shale and top basement; section 354-3; $1096 \mathrm{~m}$ depth). (d) The preserved contact between basement (porphyry) and overlying clastic sediments (section 395-2; $1215 \mathrm{~m}$ depth). (e) Volcanic porphyry as it occurs in the upper part of the basement section (section 436-3; 1304 m depth). This interval appears dark due inadvertent variation in the drilling process (polishing of the core surface by the drill bit). (f) One appearance of the rock that composes the dolerite intrusions (section 573-3; $1612 \mathrm{~m}$ depth). (g) Volcanic porphyry close to TD (section 715-7; 2111 $\mathrm{m}$ depth).

encountered in the borehole. However, the prominent reflections between $\sim 1.5$ and $2 \mathrm{~km}$ correspond, as expected, to dolerites, and show at least some deformation along their margins. We conclude the following:

- Deformation in the Alum Shale, and in the sedimentary section of the drill core in general, is less severe than expected.

- Although the Alum shale appears to be less strained than expected, we regard it as being the main detachment horizon that occurs a level of ca. 780-825 m, instead of the expected depth of ca. $1250 \mathrm{~m}$.

- The sedimentary basement cover (between top basement and Alum Shale) in the borehole (825-1250 m) appears to be substantially thicker than observed at the nearest basement window ( $\sim 30 \mathrm{~km}$ to the west) and at the present Caledonian front $(\sim 50 \mathrm{~km}$ to the east). A thicker Neoproterozoic sedimentary cover exists in northern Jämtland and Västerbotten (ca. $150 \mathrm{~km}$ to the north; e.g. Gee and Stephens, 2020). Approximately $200 \mathrm{~km}$ farther south, ca. $1.5 \mathrm{Ga}$ Jotnian sandstones (Dala sandstone) discordantly overlie the ca. 1.81.7 Ga Dala Porphyries (Lundqvist and Persson, 1999). However, the turbiditic background sedimentation in this depth interval of COSC-2 suggests that the deposition of these coarse siliciclastics happened during the initial stages of the development of the Paleozoic sedimentary basin. 


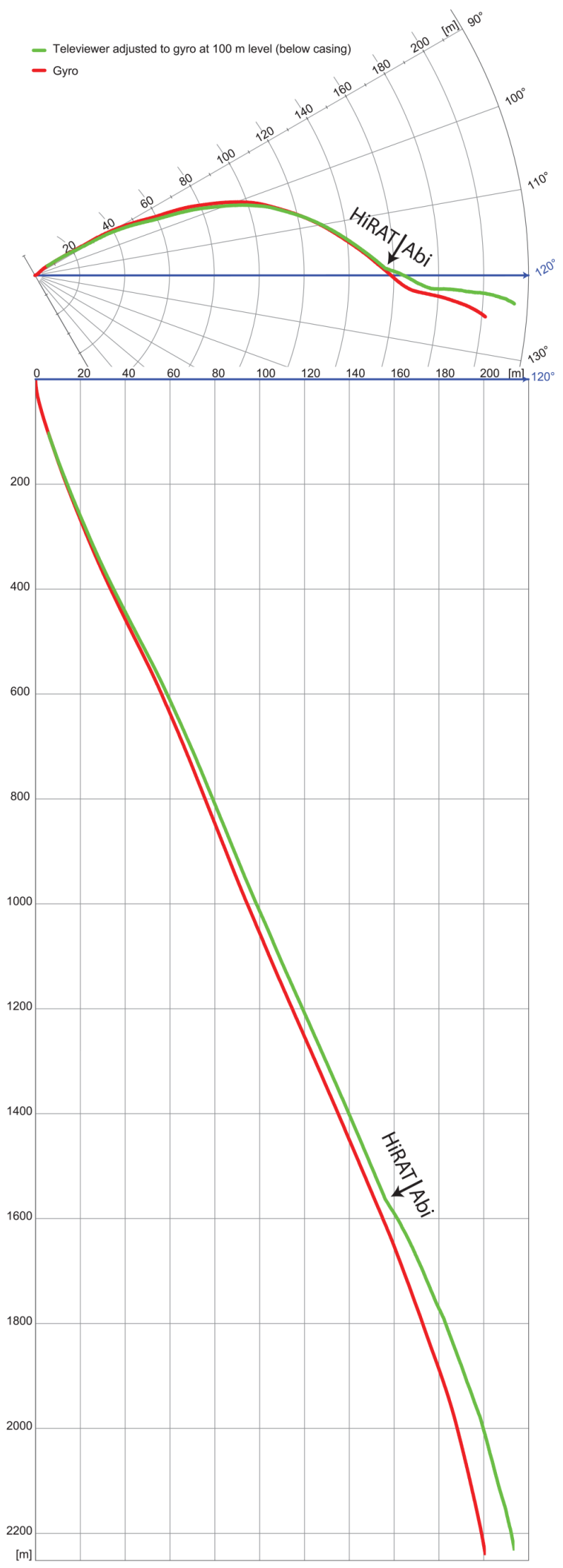

Figure 5. Borehole path of the COSC-2A borehole, based on surveys with a north-seeking gyro (red; REFLEX GYRO SPRINT-IQ ${ }^{\mathrm{TM}}$ ) and the orientation sensors of acoustic televiewers (green; derived from accelerometers and magnetometers). The televiewer data are spliced at $1570 \mathrm{~m}$, with data from the Robertson Geologging High-Resolution Acoustic Televiewer (HiRAT) above this depth and from the ALT Abi43 televiewer below this depth. 
- The conspicuous laterally continuous reflection at ca. $1250 \mathrm{~m}$ is not related to the main Caledonian décollement but to the top of the Dala Porphyries.

- Most of the prominent reflections in the basement may be caused by dolerite intrusions. The latter may also play a role in how the basement behaved and deformed during Caledonian orogeny (see Lescoutre et al., 2022).

- The basement consists of the weakly magnetic Dala Porphyries down to at least $2.3 \mathrm{~km}$ depth. In contrast to former interpretations, the Rätan-type granite that is responsible for the regional magnetic anomaly is now expected to be located at greater depth.

- Synsedimentary deformation (slumping and dewatering structures) frequently disturbs the Palaeozoic section of the drill core and may represent a common feature in the Early Paleozoic environments along this geotectonically active part of the margin of Baltica.

The differences between the expected and drilled geological sections do not affect the project's ability to address the scientific targets (1 and 3), but they will have implications for the scientific results.

An important objective of the COSC-2 drilling was to better understand the nature of the seismic reflectivity (scientific target 2). The P-wave sonic log (Fig. 6) was used as input for generating a preliminary synthetic seismogram that can be compared with the surface seismic data. First, the $\log$ was converted from depth to time, using a filtered version of the velocities and the reflection coefficient log calculated assuming constant density. This reflection coefficient $\log$ was then convolved with the first derivate of a Gaussian wavelet, with a maximum frequency of $80 \mathrm{~Hz}$, to generate the seismic response as a function of time. Good correlation is observed between the synthetic seismogram and the surface data (Fig. 7). In particular, the Alum Shale at ca. $0.32 \mathrm{~s}$ correspond to a strong reflection, as does the top of the Dala Porphyries at ca. $0.48 \mathrm{~s}$. The top of the dolerite sequence at ca. $0.6 \mathrm{~s}$ and the base of it at ca. $0.68 \mathrm{~s}$ also correlate to reflections, but more detailed studies are necessary to determine which contacts are generating the reflections within the dolerite interval. Data from the borehole seismic survey in autumn 2021 will be used to improve the time/depth conversion.

\section{Outlook}

Post-drilling borehole and surface seismic surveys were performed in autumn 2021, with the main aims of (1) investigating the nature of the seismic reflections and allowing depth conversion based on seismic frequencies, (2) increasing 3D seismic coverage in the vicinity of the borehole, and (3) studying potential anisotropy in the upper kilometres of the crust (scientific target 2). Dense sampling of the wave

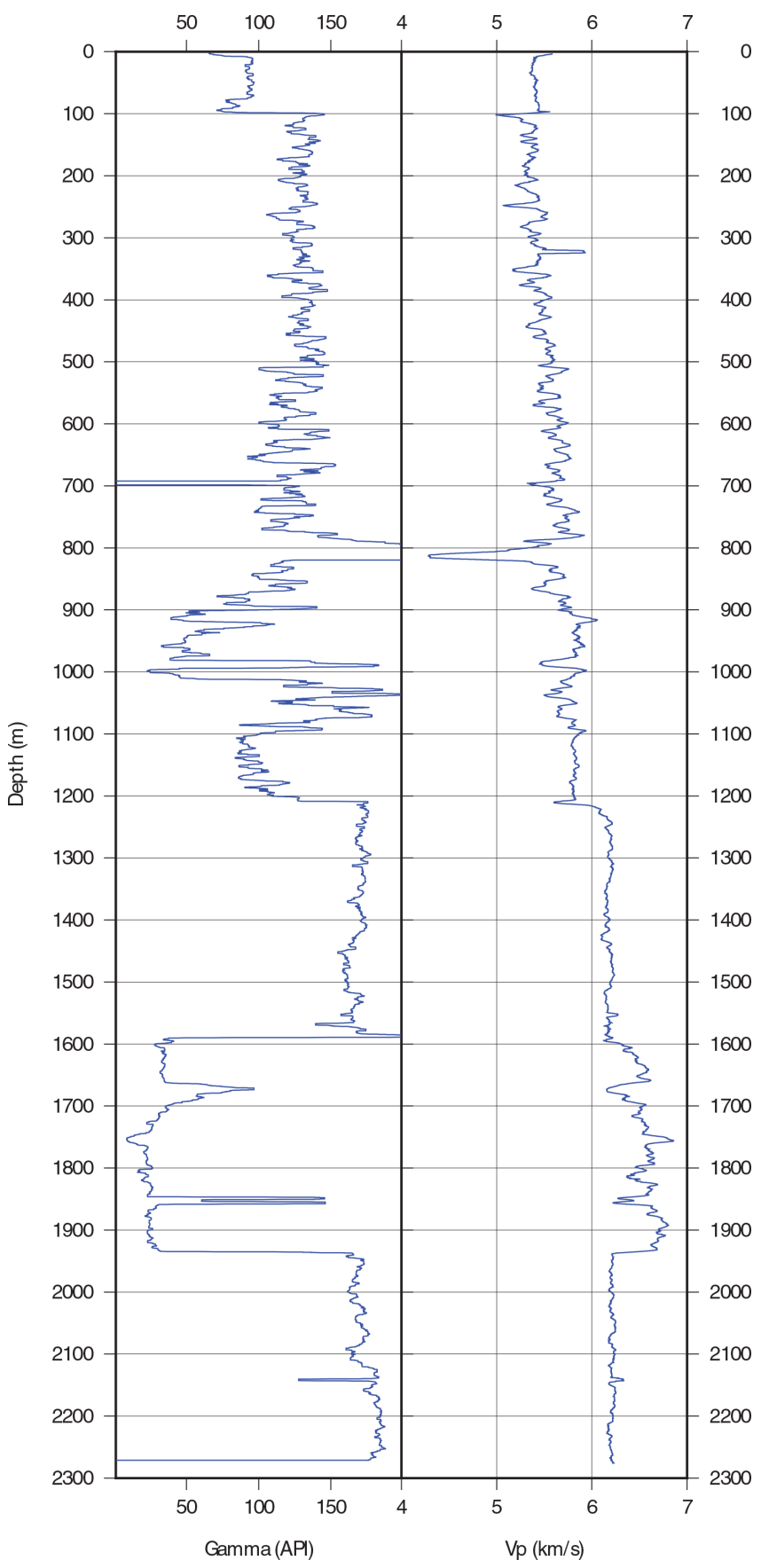

Figure 6. Natural gamma and P-wave sonic logs after smoothing. The sonic log was converted to time to form the basis for the generation of the synthetic seismogram shown in Fig. 7.

field in the borehole, a sparse 3D array on the surface, use of an airgun and lake bottom seismometers on and in Liten Lake, respectively, and a vibroseis source along two longer crossing profiles allow these objectives to be met. Field geophysics will be complemented by petrophysical measurements on core samples in the laboratory, including seismic velocities, magnetic properties (anisotropy of magnetic sus- 


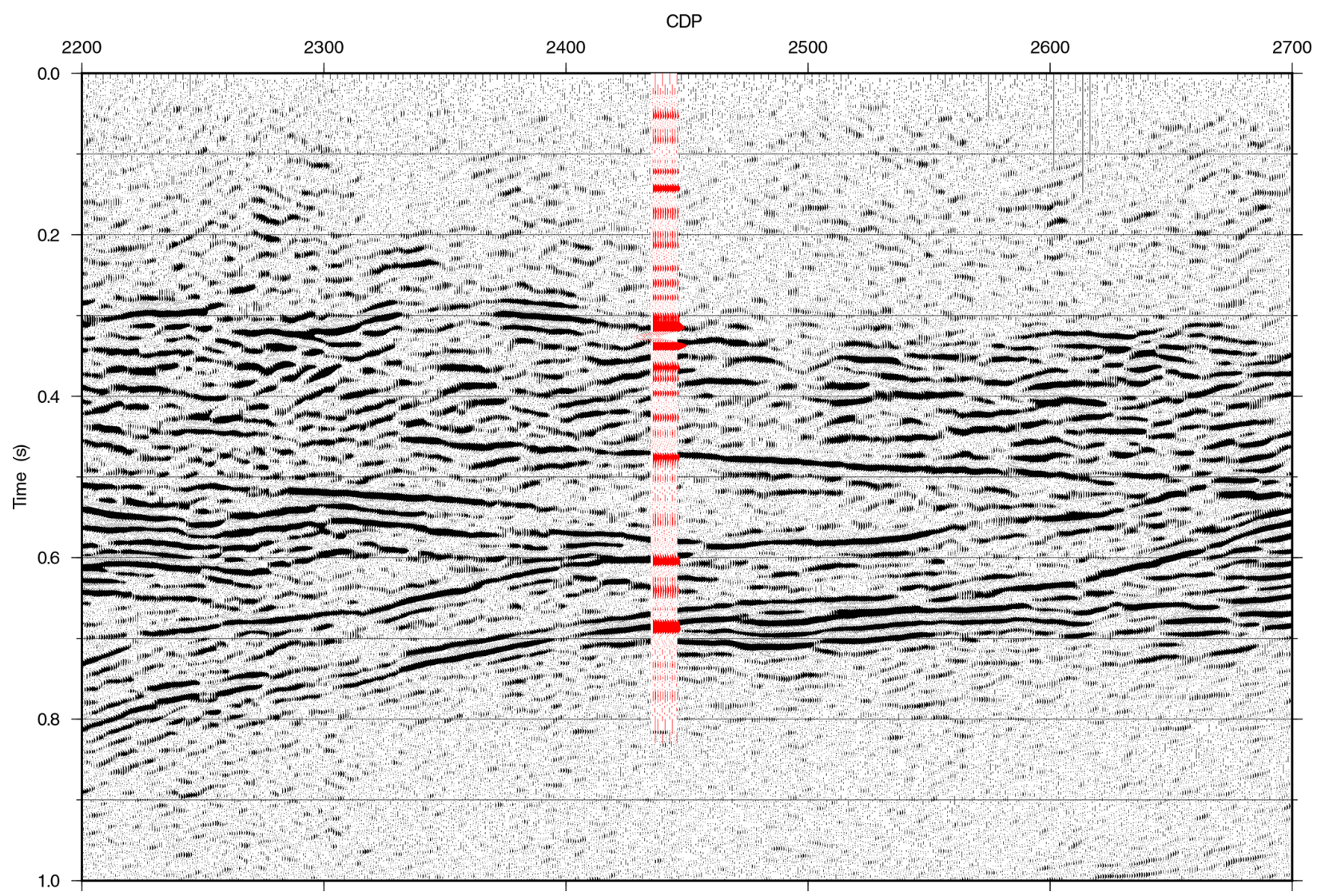

Figure 7. Synthetic seismogram (in red) with the trace repeated 10 times and plotted on top of the time-migrated surface seismic section. The synthetic seismogram was generated using the sonic log shown in Fig. 6 as input.

ceptibility (AMS) and palaeomagnetism), and electric properties of the Alum Shale.

The detailed geological description of the COSC-2 drill core was established recently and will be compiled and published by a dedicated working group from the science team. These data are critical for the scientists' preparations for the sampling party.

Scientific target 1 , to understand how deformation propagates along an orogen-scale detachment horizon and into the basement of the Fennoscandian Shield, will be advanced through additional documentation and characterisation of structures and associated alteration above, within, and below the Alum Shale. Establishing criteria for distinguishing between the Caledonian deformation and pre- and postCaledonian deformation will be critical in this regard, especially in relation to the structures identified in sections below the Alum Shale. Detailed characterisation of the detachment in the Alum Shale will help with this research. Presently, oriented subsamples are drilled from the sample series across this décollement and subjected to rock mechanical testing under controlled environmental conditions. Comprehensive microstructural and geochronological analyses will commence after the sampling party.
Analysis of the geomicrobiological samples is underway (scientific target 6). Intact cells in the prepared drill core material are detected by the CARD-FISH methodology (Escudero et al., 2020), and the diversity and taxa represented in the community are reconstructed by sequencing ribosomal RNA marker genes. If sufficient microbial biomass is retrieved, genomic reconstruction of metabolic potential will also be performed. Combined, these techniques will provide knowledge about microbial biomass, diversity, and functioning in the deep terrestrial subsurface. These will be supplemented by the characterisation of fracture mineralisation that can yield information on microbial activity in deep time (Drake et al., 2020).

Research topics related to downhole investigations have not been fully addressed yet. Hydrogeological investigations (scientific target 5) with flowing fluid electrical conductivity (FFEC) logging and fluid sampling will be conducted during 2022. This campaign is planned to be complemented with fluid sampling for geomicrobiology. The borehole temperature logging for heat flow evaluation and the modelling of palaeotemperature (scientific target 4 ) requires that the borehole temperature (Fig. 8) equilibrates to a steady state af- 


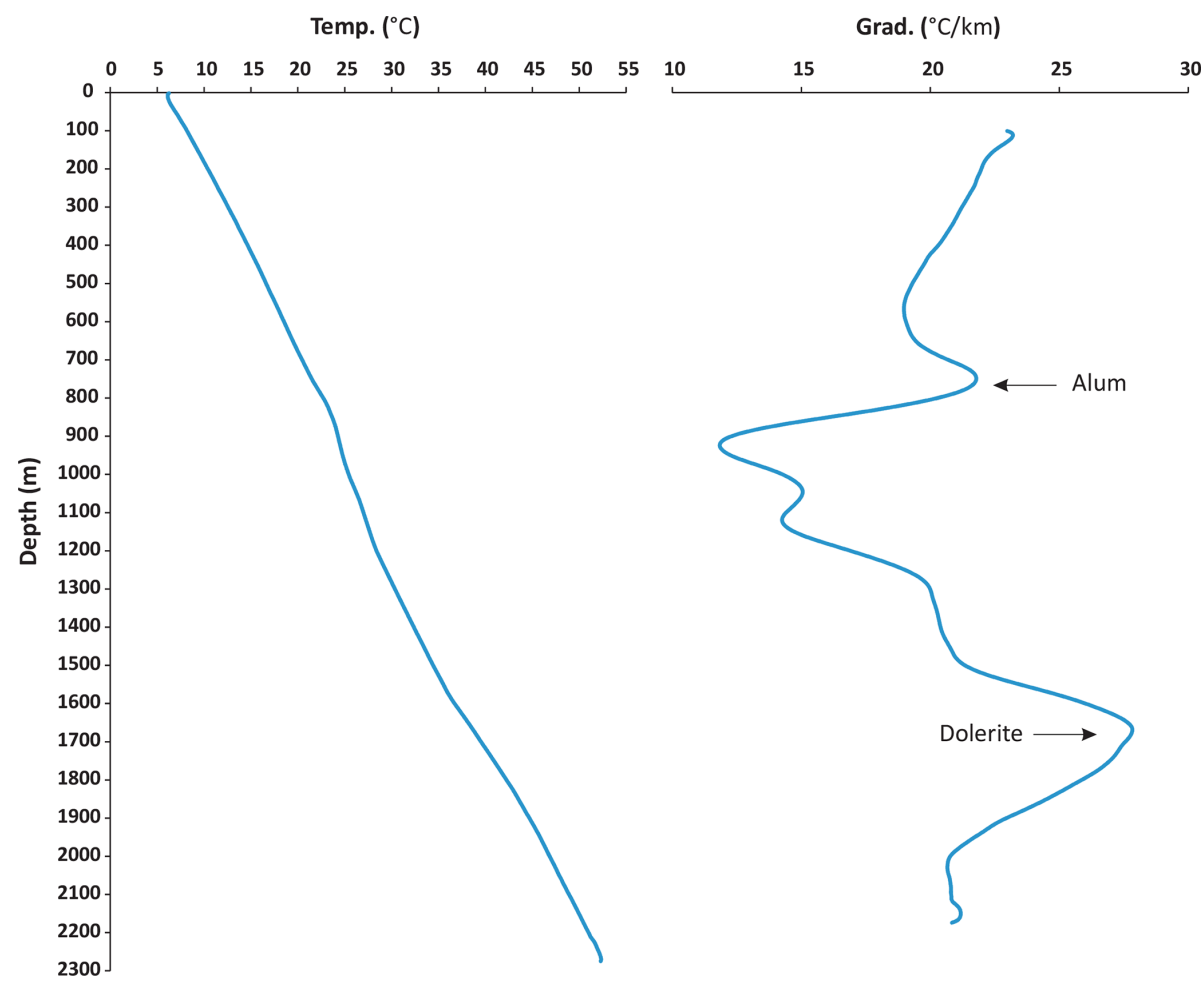

Figure 8. Temperature profile and thermal gradient for the COSC-2 drill hole. The thermal gradient was computed using a moving window of $200 \mathrm{~m}$.

ter the disturbance by the drilling operations, which usually takes several years.

During 2022, the drill site will be dismantled and renatured. A $4 \mathrm{~m}$ wide track from the road to the boreholes will provide continued access for future investigations.

\section{Summary}

The ICDP project COSC-2 drilled successfully, and within budget, to a total depth of $2276 \mathrm{~m}$ and recovered a continuous drill core of good quality with negligible core loss. The COVID-19 pandemic required some adaptations to the onsite scientific programme, like the postponement of the detailed geological description of the drill core. Observations at the drill site made clear that the drilled geological section at depth is different from the expected section. This will not affect the ability to address the scientific targets but leads to different and unexpected results. It can be stated already now that the project successfully addressed the target of understanding the seismic reflectivity in the basement by analysing downhole logs and the preliminary geological assessment of the drill core. A large downhole and surface seismic campaign will further improve on this. Expertise on microbiological research in hard rock environments has been built and protocols established that are viable for deep core drilling operations, although laboratory work and research have to show whether the biomass is sufficient, depending on rock type and depth. Geological research has begun with the (postponed) detailed description of the drill core. New insights into orogen-scale deformation are expected, including the main detachment and its influence on underlying units, and the character and age of the deformation in the basement. However, seemingly pervasive deformation in the upper part of the drill core raises the question as to how suitable it will be to help characterise the deep-water environment of the Early Paleozoic margin of Baltica (scientific target 3). Despite some setbacks, the COSC-2 project was an overall success and delivered extensive material for multidisciplinary research at a reasonable cost. The fact that the scientific community now has access to a nearly continuous composite geological section (outcrop and COSC-1 and COSC-2 drill cores) through the lower part of a major collisional orogen can be expected to generate new interest and research far beyond the present COSC project. More details about the COSC-2 operations will become available in the operational report, which will be published after the conclusion of the operational phase. The timing of the latter depends on when the COVID-19 pandemic allows the conduction of its last component, which is the sampling party.

Data availability. The COSC-2 operational data sets are published under Lorenz et al. (2021; https://doi.org/10.5880/ICDP.5054.003). 
Sample availability. The drill core of the two COSC-2 boreholes (see IGSN in Table 1 for further information) is archived at the Core Repository for Scientific Drilling at the Federal Institute for Geosciences and Natural Resources (BGR), Wilhelmstr. 25-30, 13593 Berlin (Spandau), Germany.

Author contributions. The scientific project was conceptualised by CJ, MA, MD, OL, LM, CP, and NNWR in their roles as project leader (CJ), topical principal investigators (PIs), and task leaders. Data curation was performed by JoK, for ICDP OSG downhole logging, and HL, for all other data. Funding was acquired by CJ, CP, and IK as the main applicants, with support from the co-authors and the COSC-2 science team. The investigation was led by HL, RL, GW, IK, MD, BSGA, and SB, with support from the COSC-2 on-site team. The methodology of the technical operations was designed by JER and of the operational science by HL. MD, JeK, SB, and GW developed the protocols for geomicrobiology. JER supervised the technical operations, HL supervised the operational science, and JoK and SR supervised the respective downhole logging operations. HL wrote the original draft of the paper, and JER contributed the section about the technical operations. CJ contributed the section about geophysics, and GW, SB, MD, and JeK contributed the section about geomicrobiology. CP contributed the assessment of the temperature profile. All co-authors reviewed and improved the paper.

Competing interests. The contact author has declared that neither they nor their co-authors have any competing interests.

Disclaimer. Publisher's note: Copernicus Publications remains neutral with regard to jurisdictional claims in published maps and institutional affiliations.

Acknowledgements. The authors express their appreciation for the on-site science and the drilling teams' extraordinary efforts in keeping the project running in the middle of the COVID-19 pandemic. A special thanks to drilling supervisor Stellan Larsson (also known as "The Great Wizard of the North"), from Larsson Drilling Consulting $\mathrm{AB}$, for his technical ingenuity that spared the project a lot of trouble. The drilling operations were conducted with the Swedish national research infrastructure for scientific drilling, Riksriggen, which is funded by the Swedish Research Council. The COSC-2 team thanks Nils-Olof Strandberg, for his support in local matters of all kinds. The authors thank two reviewers and the editor, for their comments that helped to improve the paper.

Financial support. A generous grant from the International Continental Scientific Drilling Project (ICDP; grant no. 4-2017) provided the financial basis for the drilling project. Co-funding for the drilling operation and operational science has been provided by the Swedish Research Council (Vetenskapsrådet; grant nos. 201903688 and 2017-00642), the German Science Foundation (Deutsche Forschungsgemeinschaft DFG, grant no. SPP 1006), and the Na- tional Science Centre of Poland (Narodowym Centrum Nauki, project no. 2018/29/B/ST10/02315).

Review statement. This paper was edited by Tomoaki Morishita and reviewed by Vincent Famin and Makoto Otsubo.

\section{References}

Andersson, A., Dahlman, B., Gee, D. G., and Snäll, S.: The Scandinavian Alum Shales, Sveriges geologiska undersökning, Uppsala, 50 pp., ISBN 91-7158-334-3, 1985.

Beckholmen, M.: Geology of the Nordhallen-DuvedGreningen area in Jämtland, central Swedish Caledonides, Geol. Fören. Stockh. Förh., 100, 335-347, https://doi.org/10.1080/11035897809454471, 1978.

Conze, R., Lorenz, H., Ulbricht, D., Elger, K., and Gorgas, T.: Utilizing the International Geo Sample Number Concept in Continental Scientific Drilling During ICDP Expedition COSC-1, Data Sci. J., 16, p. 2, https://doi.org/10.5334/dsj-2017-002, 2017.

Drake, H., Roberts, N. M. W., and Whitehouse, M. J.: Geochronology and Stable Isotope Analysis of FractureFill and Karst Mineralization Reveal Sub-Surface PaleoFluid Flow and Microbial Activity of the COSC-1 Borehole, Scandinavian Caledonides, Geosciences, 10, 56, https://doi.org/10.3390/geosciences10020056, 2020.

Dyrelius, D.: Aeromagnetic interpretation in a geotraverse area across the central Scandinavian Caledonides, Geol. Fören. Stockh. Förh., 102, 421-438, https://doi.org/10.1080/11035898009454498, 1980.

Escudero, C., del Campo, A., Ares, J. R., Sánchez, C., Martínez, J. M., Gómez, F., and Amils, R.: Visualizing Microorganism-Mineral Interaction in the Iberian Pyrite Belt Subsurface: The Acidovorax Case, Front. Microbiol., 11, 2833, https://doi.org/10.3389/fmicb.2020.572104, 2020.

Friese, A., Kallmeyer, J., Kitte, J. A., Martínez, I. M., Bijaksana, S., and Wagner, D.: A simple and inexpensive technique for assessing contamination during drilling operations, Limnol. Oceanogr. Methods, 15, 200-211, https://doi.org/10.1002/lom3.10159, 2017.

Gee, D. G. and Stephens, M. B.: Chapter 20 Lower thrust sheets in the Caledonide orogen, Sweden: Cryogenian-Silurian sedimentary successions and underlying, imbricated, crystalline basement, Geol. Soc. Lond. Mem., 50, 495-515, https://doi.org/10.1144/M50-2018-7, 2020.

Gee, D. G., Fossen, H., Henriksen, N., and Higgins, A. K.: From the Early Paleozoic Platforms of Baltica and Laurentia to the Caledonide Orogen of Scandinavia and Greenland, Episodes, 31, 44$51,2008$.

Gee, D. G., Juhlin, C., Pascal, C., and Robinson, P.: Collisional Orogeny in the Scandinavian Caledonides (COSC), GFF, 132, 29-44, https://doi.org/10.1080/11035891003759188, 2010.

Gorbatschev, R.: Beskrivning till berggrundskartan över Jämtlands län. Del 1: Urberget, Sveriges Geologiska Undersökning, Uppsala, 250 pp., ISBN 978-91-7158-569-1, 1997.

Gorbatschev, R., Solyom, Z., and Johansson, I.: The Central Scandinavian Dolerite Group in Jämtland, central 
Sweden, Geol. Fören. Stockh. Förh., 101, 177-190, https://doi.org/10.1080/11035897909448572, 1979.

Grellet, S., Boisvert, E., Simons, B., Rainaud, J.-F., Lorenz, H., Haener, R., Beaufils, M., Lieberman, J., Liu, Y., Nayembil, M., Raymond, O., Sharples, J., and Warren, P.: OGC Borehole Interoperability Experiment Engineering Report, OGC Eng. Rep., 19-075r1, Open Geospatial Consortium, 182, available at: http: //www.opengis.net/doc/per/borehole-ie (last access: 28 January 2022), 2020.

Hedin, P., Juhlin, C., and Gee, D. G.: Seismic imaging of the Scandinavian Caledonides to define ICDP drilling sites, Tectonophysics, 554-557, 30-41, https://doi.org/10.1016/j.tecto.2012.05.026, 2012.

Högdahl, K., Andersson, U. B., and Eklund, O.: The Transscandinavian Igneous Belt (TIB) in Sweden: a review of its character and evolution, Geological Survey of Finland, Espoo, 123 pp., ISBN 951-690-889-6, 2004.

Juhlin, C., Hedin, P., Gee, D. G., Lorenz, H., Kalscheuer, T., and Yan, P.: Seismic imaging in the eastern Scandinavian Caledonides: siting the $2.5 \mathrm{~km}$ deep COSC-2 borehole, central Sweden, Solid Earth, 7, 769-787, https://doi.org/10.5194/se-7-7692016, 2016.

Juhojuntti, N., Juhlin, C., and Dyrelius, D.: Crustal reflectivity underneath the Central Scandinavian Caledonides, Tectonophysics, 334, 191-210, https://doi.org/10.1016/S0040-1951(00)00292-4, 2001.

Karis, L. and Strömberg, A.: Beskrivning till berggrundskartan över Jämtlands län. Del 2: Fjälldelen, Sveriges geologiska undersökning, Uppsala, 363 pp., ISBN 91-7158-605-9, 1998.

Klonowska, I., Janák, M., Majka, J., Petrík, I., Froitzheim, N., Gee, D. G., and Sasinková, V.: Microdiamond on Åreskutan confirms regional UHP metamorphism in the Seve Nappe Complex of the Scandinavian Caledonides, J. Metamorph. Geol., 35, 541-564, https://doi.org/10.1111/jmg.12244, 2017.

Lescoutre, R., Almqvist, B., Koyi, H., Berthet, T., Hedin, P., Galland, O., Brahimi, S., Lorenz, H., and Juhlin, C.: Large-scale flat-lying mafic intrusions in the Baltican crust and their influence on basement deformation during Caledonian orogeny, GSA Bulletin, https://doi.org/10.1130/B36202.1, online first, 2022.

Lorenz, H., Rosberg, J.-E., Juhlin, C., Bjelm, L., Almqvist, B. S. G., Berthet, T., Conze, R., Gee, D. G., Klonowska, I., Pascal, C., Pedersen, K., Roberts, N. M. W., and Tsang, C.-F.: COSC1 - drilling of a subduction-related allochthon in the Palaeozoic Caledonide orogen of Scandinavia, Sci. Dril., 19, 1-11, https://doi.org/10.5194/sd-19-1-2015, 2015a.
Lorenz, H., Rosberg, J. E., Juhlin, C., Bjelm, L., Almquist, B., Berthet, T., Conze, R., Gee, D., Klonowska, I., Pascal, C., Pedersen, K., Roberts, N., and Tsang, C. F.: Operational report about phase 1 of the Collisional Orogeny in the Scandinavian Caledonides scientific drilling project (COSC1), GFZ German Research Centre for Geosciences, 55 pp., https://doi.org/10.2312/ICDP.2015.002, 2015b.

Lorenz, H., Juhlin, C., Rosberg, J.-E., Bazargan, M., Klonowska, I., Kück, J., Lescoutre, R., Rejkjær, S., Westmeijer, G., and Ziemniak, G.: COSC-2 operational report - Operational data sets, GFZ Data Services [data set], https://doi.org/10.5880/ICDP.5054.003, 2021.

Lundqvist, T. and Persson, P.-O.: Geochronology of porphyries and related rocks in northern and western Dalarna, south-central Sweden, GFF, 121, 307-322, https://doi.org/10.1080/11035899901214307, 1999.

Palm, H. and Lund, C.-E.: A seismic refraction study in the Caledonian front of Jämtland, Sweden, Geol. Fören. Stockh. Förh., 102, 561-568, https://doi.org/10.1080/11035898009454508, 1980.

Strömberg, A., Karis, L., Zachrisson, E., Sjöstrand, T., Skoglund, R., Lundegårdh, P. H., Gorbatschev, R., and Kornfält, K.-A.: Berggrundskarta över Jämtlands län utom förutvarande Fjällsjö kommun, Sveriges geologiska undersökning, Stockholm, ISBN 91-7158-605-9, 1984.

Welin, E., Christansson, K., and Kähr, A.-M.: Isotopic investigations of metasedimentary and igneous rocks in the Palaeoproterozoic Bothnian Basin, central Sweden, Geol. Fören. Stockh. Förh., 115, 285-296, https://doi.org/10.1080/11035899309453915, 1993.

Wiersberg, T., Pierdominici, S., Lorenz, H., Almqvist, B., and Klonowska, I.: Identification of gas inflow zones in the COSC-1 borehole (Jämtland, central Sweden) by drilling mud gas monitoring, downhole geophysical logging and drill core analysis, Appl. Geochem., 114, 104513, https://doi.org/10.1016/j.apgeochem.2019.104513, 2020.

Yan, P., Garcia Juanatey, M. A., Kalscheuer, T., Juhlin, C., Hedin, P., Savvaidis, A., Lorenz, H., and Kück, J.: A magnetotelluric investigation of the Scandinavian Caledonides in western Jämtland, Sweden, using the COSC borehole logs as prior information, Geophys. J. Int., 208, 1465-1489, https://doi.org/10.1093/gji/ggw457, 2016. 